\title{
O LUGAR DO EDUCANDO COMO OUTRO NA ATUAÇÃO DO EDUCADOR-BACHAREL
}

\author{
Conceição de Maria Pinheiro Barros ${ }^{1}$
}

\begin{abstract}
RESUMO: Esta investigação tem como objetivo discutir o lugar do educando na atuação do educador-bacharel universitário, na perspectiva da ética da alteridade radical. Foi realizada pesquisa qualitativa com 37 docentes-bacharéis de uma universidade pública. Fundamentando-se na bricolagem científica, recorreu-se às técnicas de questionário, entrevista compreensiva e roda de conversa. Por meio de análise do conteúdo e análise compreensiva do discurso, constatou-se que o educador-bacharel universitário pode assumir a responsabilidade pelo educando no centro do processo educativo e contribuir para o desenvolvimento de futuros profissionais responsáveis e éticos.
\end{abstract}

Palavras-chave: Educando como Outro. Educador-bacharel. Ética da alteridade radical.

\section{THE STUDENT SEEN AS THE “OTHER” IN THE PERFORMANCE OF THE BACHELOR-PROFESSOR}

\begin{abstract}
This research aims to discuss the place of the student in the performance of the university bachelor-professor, according to the ethics of radical otherness. A qualitative research was applied to 37 instructor-bachelors from a public university. Based on the scientific bricolage, we used the techniques of questionnaire, comprehensive interview, and conversation group. Through content analysis and comprehensive analysis of speech, it was found that the university educator-bachelor can take responsibility for the student at the center of the educational process, as well as contribute to the development of future responsible, and ethical professionals.
\end{abstract}

Keywords: Student as the Other. Bachelor-professor. Ethics of radical otherness.

\section{EL ESPACIO DEL EDUCANDO COMO OUTRO EN LA ACTUACIÓN DEL BACHILLER-EDUCADOR.}

RESUMEN: Esta investigación tiene como objetivo discutir el espacio de el bachiller-educador universitario, en relación a la ética de la alteridad radical. Así, fue realizada esta pesquisa cualitativa con 37 bachilleres-educadores de una

Este artigo é vinculado à pesquisa de tese no Programa de Pós-Graduação em Educação da Universidade Estadual do Ceará e ao Grupo de Pesquisa em Formação de Professores da Universidade Federal do Ceará (até 2018 sob coordenação da Profa. Dra. Ana Maria Iorio Dias). 
universidad pública. Con base en el bricolaje científico, se desarrollaran las técnicas de cuestionarios, entrevistas comprensivas y rodas de conversa. Mediante análisis de contenido y análisis comprensivo del discurso, se comprobó que el bachillereducador universitario puede asumir la responsabilidad por el educando en el centro del proceso educativo y contribuir al desarrollo de futuros profesionales responsables y éticos.

Palabras-clave: Educando como Otro. Bachiller-educador. Ética de la alteridad radical.

\section{Introdução}

\section{A}

lves (1980) propõe distinção entre ser professor e ser educador. O educador possui uma "estória" a ser contada e habita um mundo de relacionamentos que fazem um elo com os estudantes, os quais, por sua vez, possuem identidades e a própria "estória". A educação deve acontecer nesse espaço que não se vê, mas é estipulado a dois. Por outro lado, o professor é habitante “[...] de um mundo diferente, onde o 'educador' pouco importa, pois o que interessa é um 'crédito' cultural que o aluno adquire numa disciplina identificada por uma sigla [...].” (ALVES, 1980, p. 12).

Acrescentamos a esse debate a alteridade por considerarmos a subjetividade das relações estabelecidas entre educador e educando para a construção de conhecimentos, com fundamentação na filosofia de Emmanuel Lévinas, a qual considera o Outro $^{1}$ em primeiro lugar na relação ética. Lévinas (1980) coloca a ética como filosofia primeira. Para tanto, o Outro deve ser sempre mais importante que o Eu, o que justifica a radicalidade de sua teoria.

Esta pesquisa tem a seguinte questão central: "Qual é o lugar do educando na atuação do educadorbacharel universitário, sob a perspectiva da ética da alteridade radical?” Pressupomos que a docência universitária seja uma área de atuação para o bacharel, cujos saberes pedagógicos não são contemplados em sua formação inicial, o que o leva a tornar-se professor sem a formação necessária para sua constituição como educador.

Refletimos que "[...] a ausência de saberes pedagógicos limita a ação docente e impacta diferentes obstáculos ao processo de ensinar e aprender” (VOSGERAU et al., 2017, p. 233), especialmente, na perspectiva levinasiana. O objetivo principal é discutir o lugar do educando na atuação do educador-bacharel universitário, na perspectiva da ética da alteridade radical.

Em um levantamento de estudos acerca da temática, selecionamos 85 trabalhos. Identificamos sete pesquisas sobre ética da alteridade radical e educação. Não localizamos investigações direcionadas ao docente universitário como educador levinasiano, tampouco ao docente-bacharel. Entre os estudos encontrados (GUEDES, 2007; MIRANDA, 2008; COUTINHO, 2008), observamos lacunas no tocante aos subsídios empíricos. Assim, "[...] o objetivo de abordar a educação desde a ética da alteridade em Lévinas permanece ainda um caminho aberto a ser percorrido" (MIRANDA, 2008, p. 180).

Guedes conclui: "E uma pergunta que brota do interior desse filosofar é sobre os desdobramentos práticos que uma pesquisa como esta pode provocar” (2007, p. 176). Evidencia-se a carência de pesquisas empíricas sobre a filosofia levinasiana e a educação. Destacamos a importância deste estudo por ampliar a discussão acerca da formação do bacharel que se torna docente, ao trazer aos debates a perspectiva do educador e incluir no cerne da questão a alteridade levinasiana. Apresentamos novas definições relacionadas à interação da formação pedagógica com a prática profissional do bacharel como educador por meio de subsídios teóricos e empíricos. 


\section{Reflexões acerca da ética da alteridade radical: a responsabilidade pelo outro}

Emmanuel Lévinas, filósofo francês, recebeu uma educação judaica tradicional. O contexto no qual Lévinas propôs reaver a valorização do ser humano por meio da ética da alteridade radical, o século XX, foi assinalado por duas grandes guerras mundiais, que culminaram em desventura, aflição e morte, cujas marcas de terror e sofrimento afetaram a sociedade. A humanidade não somente vivenciou uma época de grande violência com o uso de forças armadas, mas também de desvalorização do ser humano. Por ter presenciado as duas guerras mundiais, o pensamento filosófico do autor possui como "pano de fundo" a experiência do domínio do ser humano para com outro ser humano, numa total ausência de amor ao próximo. Consideramos que "a guerra exprime uma alteridade infeliz, que desviou; não manifesta a verdadeira alteridade, mas, antes, 'destrói a identidade da mesma'” (MARTINS; LEPARGNEUR, 2014, p. 18).

Para a filosofia levinasiana o termo "alteridade" excede o significado de diferente, pois o Outro não é somente distinto do Eu. Ele permanece sempre como Outro, o qual emerge como Rosto que invoca o Eu a uma obrigatoriedade de respondê-lo. O Rosto supera uma visão fenomenológica, pois a fenomenologia pressupõe uma descrição do que se apresenta.

A maneira pela qual se apresenta o Outro ultrapassa $a$ ideia do Outro em mim, nós a chamamos, em efeito, olhar. [...] O olhar de Outrem destrói a todo momento e transborda a imagem plástica que ele me deixa, a ideia à minha medida e à medida de seu ideatum - a ideia adequada(LÉVINAS, 1988, p. 43, grifos do autor).

A responsabilidade levinasiana considera que o Outro deve vir antes do Eu; o Outro é o centro da relação, o que coloca em questão a liberdade do Eu: "Entendo a responsabilidade como responsabilidade por outrem, portanto, como responsabilidade por aquilo que não fui eu que fiz, ou não me diz respeito, é por mim abordado como rosto" (LÉVINAS, 1982, p. 79).

Na racionalidade moderna, privilegia-se a liberdade; a pessoa é considerada autônoma em sua decisão acerca de sua responsabilidade. O Eu é independente para definir sobre o que se sente responsável ou não. Em contraposição, Lévinas (1982) defende uma responsabilidade total, na qual o Eu responde por todos os outros; tem sempre uma responsabilidade a mais.

A responsabilidade, na teoria levinasiana, é um dever que emerge nas relações sociais, visto que se pertence a um mundo social. Compromisso invocado no encontro do Mesmo com o Rosto, o qual “[...] abre o discurso original, cuja primeira palavra é obrigação que não se permite evitar" (MARTINS; LEPARGNEUR, 2014 , p. 7). Trata-se de apelo do Outro e resposta do Mesmo. Entretanto, não significa um pedido, mas um mandamento. Segundo Lévinas: “[...] na relação interpessoal, não se trata de pensar conjuntamente o eu e o outro, mas de estar diante" (1982, p. 63) e requer uma resposta às necessidades e expectativas do Outro. Para Hutchens, "nunca estamos sós e sim 'cara a cara' com outras pessoas que nos pedem que reconheçamos nossas responsabilidades para com elas" (2009, p. 36).

Liberdade e responsabilidade não são excludentes; trata-se da subordinação da liberdade à responsabilidade. "A outra pessoa quer algo que devemos dar, mas o que é precisamente que ela quer?" (HUTCHENS, 2009, p. 40). Na percepção de Martins e Lepargneur, "a responsabilidade antecede a liberdade. O critério decisivo é o Outro que antecede o Eu. A liberdade do Eu esbarra na responsabilidade pelo Outro" (2014, p. 8). O dever de oferecer resposta não é passível de transferência; a responsabilidade pelo Outro é insubstituível. "Se a responsabilidade é indeclinável e não é escolhida, então, não podemos dizer: 'outra pessoa pode assumir essa responsabilidade”" (HUTCHENS, 2009, p. 40). 
"O Outro é a razão que fundamenta o Eu. Essa razão dialogal na confrontação entre dois seres não é abstrata, mas o encontro com o totalmente nu, com o fato último expresso no olhar do estrangeiro [...]" (MARTINS; LEPARGNEUR, 2014, p. 8). Na relação com o Rosto, por meio de uma responsabilidade do Eu para com o Outro, que, ao olhar, exige um retorno, concretiza-se a ética da alteridade radical. Significa sair de si mesmo em um movimento em direção ao Outro, servir ao Outro sem esperar algo em troca.

A alteridade radical não significa somente respeitar o diferente, mas acolher a diferença; abrigar o Outro, o qual será sempre Outro. Diz-se "radical" porque considera o Outro como mais importante do que o $\mathrm{Eu}$; desde o instante em que surge o encontro com o Outro emerge uma obrigação de responder a ele. O Outro deve estar em primeiro lugar, numa responsabilidade que não pode ser omitida e está acima da liberdade. Não é uma questão de escolha, não há como fugir dessa incumbência: o papel do Eu é intransferível. Essa ética se diferencia da perspectiva de alteridade limitada à tolerância ao diferente. A filosofia levinasiana conclama a ética da obrigatoriedade em acolher a diferença. É com o amparo dessas interpretações que discutimos acerca do educador-bacharel sob o olhar da ética em Lévinas.

\section{O percurso teórico-metodológico da pesquisa por meio da bricolagem científica}

Esta investigação foi desenvolvida numa abordagem qualitativa compreendida como “[...] naturalista, interpretativa, para o mundo, o que significa que seus pesquisadores estudam as coisas em seus cenários naturais [...]" (DENZIN; LINCOLN, 2006, p. 17). Tem como paradigma a fenomenologia, consistente na "[...] compreensão dos fenômenos em suas várias manifestações, na elucidação dos pressupostos, dos mecanismos ocultos, das implicações, dos contextos [...]” (GAMBOA, 2012, p. 55).

A interpretação do fenômeno investigado buscou a identificação de manifestações da ética da alteridade radical, com procedência nos sentidos ocultos nos discursos dos sujeitos sobre a sua atuação na docência universitária. Fundamenta-se na bricolagem científica (KINCHELOE; BERRY, 2007), caracterizada pela utilização de uma diversidade de práticas de coleta e interpretação de informações, para que o investigador alcance seus objetivos.

\section{Campo de pesquisa e seleção dos sujeitos}

Compreendemos o universo investigativo como "[...] um conjunto definido de elementos que possuem determinadas características” (GIL, 2006, p. 99). Nesta pesquisa, o universo foi composto por uma universidade pública do Nordeste brasileiro. Os sujeitos foram constituídos por representantes docentes eleitos em obediência aos seguintes critérios: ser bacharel; ter experiência mínima de cinco anos na docência universitária; atuar como docente universitário; ter disponibilidade; e aceitar a proposta da pesquisa.

Para fazer um recorte temporal, selecionamos docentes-bacharéis que estavam participando de ações de formação docente na Universidade, ou as haviam concluído, no período de 2009 a 2016. Foram convidados 144 docentes-bacharéis, dos quais 37 aceitaram participar da pesquisa.

\section{As estratégias da pesquisa}

Foi feito o entretecimento de técnicas de coleta de informação a partir do princípio da bricolagem metodológica, que "emprega muitas estratégias de coleta de dados" (BERRY, 2007, p. 145). Inicialmente, 
recorremos à técnica de aplicação de questionário, definida como “[...] técnica para obtenção de informações sobre sentimentos, crenças, expectativas, situações vivenciadas e sobre todo e qualquer dado que o pesquisador deseja registrar para atender os objetivos de estudo" (OLIVEIRA, 2010, p. 83). O questionário foi enviado por meio de correio eletrônico, com a utilização do software e ferramenta de pesquisa on-line denominado SurveyMonkey. ${ }^{2} \mathrm{O}$ questionário foi composto por quatro questões, abertas e fechadas, sobre a relação educador-educando e o processo de ensino-aprendizagem, e foi aplicado em três momentos.

Primeiramente, o instrumento foi direcionado aos docentes-bacharéis que haviam concluído atividades formativas na Universidade, tendo a participação de 23 sujeitos. Na sequência, o questionário foi aplicado aos 14 docentes-bacharéis que estavam cursando ações formativas. A terceira etapa de aplicação visou obter informações acerca dos saberes docentes articulados na atuação do docente-bacharel. Oliveira (2010) recomenda a realização de pré-teste após a elaboração do questionário. Foram realizados testes com três professoras que possuíam o perfil desejado para a pesquisa. Em seguida, realizamos melhorias, visando a maiores precisão e objetividade do instrumento.

Por conseguinte, com base nas respostas, selecionamos os docentes-bacharéis que demonstraram possuir perfil de educadores para participarem das demais fases da pesquisa. Foram convidados 18 docentes-bacharéis, entre os quais 11 concordaram em continuar contribuindo com a investigação.

A entrevista compreensiva permitiu o aprofundamento sobre o tema por meio dos discursos dos participantes, pois “[...] não é apenas uma técnica, mas um método de trabalho diferenciado e com propósitos claros, visando à produção teórica a partir dos dados” (CAVALCANTI, 2013, p. 8). Para seu desenvolvimento, foi necessário utilizar alguns instrumentos evolutivos. Desenvolvemos um plano evolutivo que consiste na escrita de todas as etapas de exploração dos dados, com modificações a cada dia. Empregamos a grade como um guia sobre a temática (KAUFMANN, 2013). A grade abordou aspectos relacionados às manifestações da ética da alteridade radical, bem como às possibilidades de atuação na perspectiva levinasiana. Realizamos um pré-teste da grade com dois docentes-bacharéis, seguidos de melhorias no instrumento.

As entrevistas foram individuais, iniciando-se com uma explanação sobre a filosofia levinasiana e, após, com abordagem dos assuntos a serem discutidos. O registro das conversas foi feito por meio de gravador de voz. Encontramos, na entrevista compreensiva, aproximações com a bricolagem, visto que esse modelo considera a existência de “[...] uma dimensão improvisada, intransferível e em grande parte autoconstruída. Isso torna a prática científica um processo de verdadeira bricolagem permanente, uma construção in situ no ato mesmo de sua efetivação" (CAVALCANTI, 2013, p. 7).

Utilizamos a técnica denominada "roda de conversa", por termos percebido a necessidade de aprofundamento sobre o tema. A roda de conversa pode ser compreendida como "[...] uma forma de produzir dados em que o pesquisador se insere como sujeito da pesquisa pela participação na conversa e, ao mesmo tempo, produz dados para discussão" (MOURA; LIMA, 2014, p. 99). Para tanto, foram convidados os 11 sujeitos participantes da etapa de entrevista, dos quais cinco compareceram.

A roda de conversa "[...] permite a partilha de experiências e o desenvolvimento de reflexões sobre as práticas educativas dos sujeitos, em um processo mediado pela interação com os pares, através de diálogos internos e no silêncio observador e reflexivo" (MOURA; LIMA, 2014, p. 99). Consideramos importante que os participantes conhecessem a concepção levinasiana e, assim, pudessem pensar sobre os conceitos na sua prática docente. Foi enviado aos sujeitos, com uma semana de antecedência, um texto sobre a teoria de Lévinas. O diálogo foi fundamentado no texto, conforme roteiro elaborado como guia da conversa, com base na teoria levinasiana. A conversa foi filmada, tendo duração de 1h56min. 


\section{Percursos da análise: a bricolagem interpretativa}

$\mathrm{Na}$ bricolagem científica, é possível empregar “[...] uma gama de estratégias interpretativas que emerge de uma consciência detalhada do campo da hermenêutica [...]” (BERRY, 2007, p. 145). Para os dados alcançados por meio do questionário, realizamos análise do conteúdo (BARDIN, 2009), pois "o ato interpretativo na bricolagem deve promover o desvendar de significados e sentidos expressos pelos diferentes sujeitos” (NEIRA; LIPPI, 2012, p. 612).

Na pré-análise, foram feitas a organização dos dados obtidos, a leitura e a organização das respostas. Na etapa de exploração do material, foi realizada a análise propriamente dita, por meio de sistematização e codificação dos dados. Com relação ao tratamento dos resultados e à interpretação, as informações foram organizadas na ficha de registro e interpretação, para possibilitar a identificação dos indicativos de análise. À luz da hermenêutica, a análise visou à compreensão de aspectos fundamentais para o alcance dos objetivos (PALMER, 2006).

A análise compreensiva do discurso foi eleita para interpretar as informações obtidas por meio das entrevistas e da roda de conversa. Fundamentou-se na multirreferencialidade, considerando-se que essa última propõe "uma leitura plural de tais objetos sob diferentes ângulos e em função de sistemas de referência distintos não supostos redutíveis uns aos outros, eventualmente reconhecidos mutuamente heterogêneos" (ARDOINO, 2012, p. 87).

$\mathrm{Na}$ bricolagem, a interpretação da pesquisa considera a diferença entre descrever e compreender um fenômeno, envolvendo, segundo Kincheloe (2007c), o elo entre o objeto de estudo e os vários contextos nos quais ele se insere; a relação entre investigador e objeto investigativo; a junção entre a elaboração de sentido e a experiência humana; a utilização de textos analíticos, considerando que os seres humanos são as entidades em torno das quais e com as quais o significado está sendo elaborado; e a conexão entre as formas de visão e ação informada.

\section{"Não me matarás de fome de aprender": qual é o lugar do educando como outro?}

Nesta seção, abordamos os resultados da pesquisa empírica, considerando que o educando tem "fome de aprender". É a fome que põe em funcionamento o aparelho pensador. “[...] O 'afeto' é o movimento da alma na busca do objeto de sua fome" (ALVES, 2004, p. 22). Na esteira do pensamento levinasiano, o educador é invocado a saciar a fome do educando, visto que o Rosto apela e, por meio do olhar, fala: "tu não matarás" (LÉVINAS, 1982, p. 70). Com o apelo no olhar exposto no Rosto, o Mesmo torna-se responsável pelo Outro, devendo responder-lhe: "Eis-me aqui [...] quando a vida parece dirigir-se numa direção totalmente oposta” (LÉVINAS, 1982, p. 90).

O Rosto do educando (Outro) fala: "tu não me matarás". Como é possível escutar esse chamado? "Basta contemplar os olhos amedrontados das crianças e os seus rostos cheios de ansiedade para compreender que a escola lhes traz sofrimento" (ALVES, 1994, p. 11). Então, como se "mata" o Rosto do educando (Outro)? Expomos a consideração de uma entrevistada, ao discorrer acerca do seu compromisso com o educando (Outro):

O docente tem uma influência muito forte na vida das pessoas e, assim, você acaba conseguindo destruir alguém. Você tem o poder em sala de aula, você pode acabar com uma pessoa, como 
você pode enaltecer a ponto de ela até se descobrir [...]. Assim como tem educandos que sentem verdadeira aversão a determinados professores por conta da postura deles e esses professores acabam sendo até certo ponto egoístas, porque eles não tão preocupados com o Outro [...] (EDUCADORA-BACHARELA 8, grifos nossos).

O citado discurso denota modos como o professor pode "matar" o educando (Outro). A entrevistada utiliza palavras como "destruir", “acabar”, “aversão" e "egoísmo". Tais termos são utilizados para expressar exemplos de resultados negativos da influência do educador na vida do educando. O educador pode utilizar sua influência e agir sobre o educando de modo negativo, de tal maneira que desestimule seu desenvolvimento acadêmico e/ou profissional, desvalorize sua capacidade de ser mais, de crescer, de ir além, e "mate" sua motivação, seu interesse, seus sonhos. Alves (1980) postula que a educação se desenvolve em um espaço invisível estipulado a dois. Na intersubjetividade e inter-relação que o professor, ocupado com o "crédito" da disciplina, pode "matar" a aprendizagem do educando.

O educando, na condição de Rosto, conclama: "não me matarás". O Rosto do educando interpela ao educador: "[...] por favor, me ajude a ser feliz" (ALVES, 1994, p. 15). Trata-se de um chamado à responsabilidade. O modo como o Outro se apresenta não expõe a formação de uma imagem conforme o ideário do Eu (LÉVINAS, 1988). Respeitar o educando é mais do que tão-somente aceitar as suas diferenças, pois se faz imperativo ético reconhecê-lo como totalmente Outro, capaz de trilhar seu percurso em direção à construção do novo, da transformação daquilo que ele já conhece.

A filosofia levinasiana, na prática do educador, demanda uma atuação que não desvie a alteridade genuína e preserve a identidade do educando (MARTINS; LEPARGNEUR, 2014). Ao desconsiderar tal identidade, o professor passa a objetivá-lo. O processo educativo voltado para o ser humano como objeto caminha em sentido oposto à educação pensada por Lévinas. Interessa-nos uma educação preocupada com o humano-sujeito, o educador que desenvolve suas atribuições para o educando-sujeito totalmente Outro, que possui experiências e opiniões, a ser colocado como sujeito reflexivo acerca do tempo e do espaço. "Trata-se, pois, de uma relação entre os seres humanos, que desponta como algo totalmente irredutível ao conhecimento e à representação, uma relação que respeita e resguarda a alteridade do Outro enquanto Outro" (ALVES; GHIGGI, 2012, p. 580).

Como pode ocorrer a representação na educação? Uma representação acontece quando o professor, ao se considerar detentor do saber, age como opressor (FREIRE, 1987), limita o potencial do educando e estabelece paradigmas acerca de sua capacidade cognitiva. Ao eliminar a possibilidade de desenvolvimento intelectual, o educador objetiva o educando como ser que está na instituição para aprender conteúdo, desconsiderando sua capacidade de constituir saberes. Exclui a alteridade do educando o professor que

[...] desrespeita a curiosidade do educando, o seu gosto estético, a sua inquietude, a sua linguagem, mais precisamente, a sua sintaxe e a sua prosódia, o professor que ironiza o aluno, que o minimiza, que manda que "ele se ponha em seu lugar" ao mais tênue sinal de sua rebeldia legítima [...] (FREIRE, 1996, p. 25).

O professor objetiva o educando ao limitar sua capacidade de desenvolvimento, em um modelo de educação tradicional. Em tal modelo, “[...] o singular passa ao universal, o Outro fica como que suspenso e privado de permanecer em sua alteridade, e acaba fazendo parte de um sistema total" (ALVES, GHIGGI, 2012, p. 581). Resta ao educando comportar-se conforme os preceitos impostos pelo sistema, ou seja, impera a objetivação do ser. Eis um comentário que exemplifica a não objetivação do educando: 
Mas quando surge uma coisa assim: professora, eu discordo disso. Tá. E porque você discorda? Aí eu procuro ver o que é e digo assim: tá bom, eu vou pensar sobre isso que você tá me falando, eu ainda não consigo concordar com você, mas eu juro que eu vou pensar [...], mas eu também nunca digo a ele "deixe de pensar como você pensa e pense como eu" (EDUCADORABACHARELA 6, grifos nossos).

Essa consideração ratifica a filosofia levinasiana na atuação do educador-bacharel, pois nega a propriedade do Outro ao Mesmo; o Eu não se volta para si mesmo, reconhecendo o impacto do encontro entre o Mesmo e o Outro, e respeita a alteridade como tal (MARTINS; LEPARGNEUR, 2014).

A objetivação do educando se desencadeia no modelo de ensino fundamentado na transposição de informações, de saberes já experimentados, os quais têm “[...] uma função econômica: a de poupar trabalho, a de evitar erros, a de tornar desnecessário o pensamento. Assim, aprende-se para não precisar pensar. Sabendo-se a receita, basta aplicá-la quando surge a ocasião" (ALVES, 1994, p. 23).

A educação segundo Lévinas não ocorre no encontro professor-aluno como "[...] un encuentro no del que sabe con el que no sabe, del profesor con el alumno, en un ejercicio de transmisión de saberes, sino el encuentro del que se sabe responsable del otro, obligado a darle una respuesta en su situación de radical alteridad" (RUIZ, 2004, p. 8) ${ }^{3}$. O processo educativo não se desenvolve entre um que domina o saber e outro que está ali somente para recebê-lo, mas entre um que reconhece a sua responsabilidade para com o caminho em direção à aprendizagem e Outro que o invoca a respondê-lo. Lévinas (1982) compreende a radicalidade de uma incumbência em relação a outrem, por aquilo que o Eu não realizou.

Alves pondera que "a educação, fascinada pelo conhecimento do mundo, esqueceu-se de que sua vocação é despertar o potencial único que jaz adormecido em cada estudante” (1994, p. 14). Isso significa considerar a sua infinitude, a capacidade que ele possui de ir além, de constituir o novo, de sonhar e realizar. Nessa relação, o educador precisa considerar "a subjetividade como acolhendo Outrem, como hospitalidade. Nela se consuma a ideia do infinito" (LÉVINAS, 1980, p. 14). Alves e Ghiggi analisam que "[...] é possível pensar as bases sobre as quais se estrutura uma matriz de educação, em nosso juízo, humanizadora, pautada no acolhimento do Outro na sua infinitude” (2012, p. 579).

Educar consiste na escuta, pois "o educador que escuta aprende a difícil lição de transformar o seu discurso, às vezes necessário, ao aluno em fala com ele” (FREIRE, 1996, p. 43). Com relação à escuta, destacamos:

Sempre ao término de cada conteúdo [...] eu pergunto exatamente: "Ficou claro?", "Alguma dúvida?” E aí, nesse momento, é feita uma checagem em relação ao conteúdo em si. [...] Sempre que há alguma dúvida, eu esclareço. [...] A gente vai a fundo até dirimir tudo (EDUCADORA-BACHARELA 1).

A atenção da citada educadora está voltada para o processo de ensino-aprendizagem. Invocamos Lévinas ao considerar a escuta do Outro no sentido de que "ouvir a sua miséria que clama por justiça não consiste em representar-se uma imagem, mas em colocar-se como responsável [...]” (1980, p. 193). Pensar a educação nesse entendimento oferece condições para "aprender a olhar, a escutar, a sentir e a cuidar do outro" (COUTINHO, 2008, p. 22), numa relação não impositiva.

Para Miranda, “[a] educação, antes de constituir como pergunta, acontece como resposta a essa permanente inquietação que vem do Outro" (2008, p. 144), inquietação essa percebida na escuta, que “[...] significa a disponibilidade permanente por parte do sujeito que escuta para a abertura à fala do outro, ao gesto do outro, às diferenças do outro" (FREIRE, 1996, p. 45). Contudo, não se refere à possibilidade 
unicamente auditiva, mas ao processo educativo instaurado por meio da relação face a face com o Outro. Trata-se de descobrir a nossa humanidade e desobscurecer o bem por meio do encontro (COUTINHO, 2008) entre educador e educando.

Com base em Lévinas (1980, 2002, 2005), consideramos que o educador (Eu) contribui para a constituição de conhecimento do educando (Outro) na acolhida à sua alteridade. Até que ponto o educador-bacharel (Eu) se considera responsável pela aprendizagem do educando (Outro)?

Foi questionado aos entrevistados se eles se acham responsáveis pela aprendizagem do educando e como se sentiriam caso os educandos não atingissem os resultados almejados. Uma entrevistada afirmou: “Totalmente. Sofro com isso também. Se você chegar ao final do semestre, se você perceber que ninguém entendeu, que horror! Aí eu acho que eu me sentiria péssima” (EDUCADORA-BACHARELA 6). O senso de responsabilidade pelo educando é tão marcante em sua atuação que imaginar a possibilidade de um resultado negativo na aprendizagem a faz pensar em um abalo emocional. Na esteira desse pensamento, destaca-se:

Eu me acho muito responsável [...] eu vejo que essa responsabilidade, ela se faz presente dentro da relação com a alteridade, mas também como exigência a ser cumprida. Sinto e me cobro por isso. Que realmente ele tenha uma aprendizagem mínima pra passar na disciplina (EDUCADORA-BACHAREL 9).

O sentimento de obrigatoriedade por parte da citada educadora em relação à aprendizagem do educando é perceptível em sua fala, ao expor que sente uma cobrança pessoal para que o educando aprenda o essencial. Podemos intencionar uma educação mediada por uma responsabilidade percebida em um sujeito histórico (COUTINHO, 2008). A responsabilidade ilimitada pelo Outro é retratada por Lévinas (2000, p. 90), ao asseverar que "somos todos culpados de tudo e de todos perante todos, e eu mais do que os outros".

Existem limites para a responsabilidade do educador $(\mathrm{Eu})$ pela aprendizagem, visto que essa se relaciona com o educando (Outro)? A fala de uma entrevistada denota uma responsabilidade compartilhada: "ambos fazendo nossa parte no processo de aprendizagem, mas, mesmo assim, se o resultado não foi favorável 'aí sim, eu teria uma responsabilidade"' (EDUCADORA-BACHARELA 1). Essa opinião é ratificada a seguir: "[...] quando você depara com um aluno que é desinteressado mesmo, então não cabe mais a você, você vai até certo ponto” (EDUCADORA-BACHARELA 9).

A Educadora-Bacharela 9 questionou o desinteresse do educando em aprender; já a EducadoraBacharela 10 salientou que sua atuação possui delimitação e que o resultado não depende dela. Contudo, o que leva um educando a se desinteressar em relação à aula? Não teria a educadora nenhuma responsabilidade em relação ao seu desinteresse? O que o educador pode fazer para motivá-lo?

Ao considerar um determinado aluno "desinteressado mesmo", a Educadora-Bacharela 9 faz uma representação do educando. Afirma que não há solução para que o educando aprenda. Seria esse o papel do educador? Uma participante ponderou: "[...] a partir do momento que a minha atuação termina, eu não tenho mais nenhum controle sobre o que vai acontecer. [...]" (EDUCADORA-BACHARELA 10). Essa consideração corrobora a percepção de que, na prática dos docentes investigados, há uma limitação para a responsabilidade do educador. Outros participantes concordaram:

O aprendizado depende mais do aluno do que do professor. [...], mas não adianta nada o meu melhor esforço se ele não fizer o esforço dele. Eu não tenho como fazer isso. Então, eu não me considero completamente responsável por isso (EDUCADOR-BACHAREL 2). 
[...] O que eu tento fazer? É que aquele período da minha disciplina seja um período de crescimento [...]. Mas eu acho que o grande responsável é sempre o aluno, o mérito é sempre do aluno [...] (EDUCADOR-BACHAREL 3).

Essas afirmativas surgem como lacunas em relação à perspectiva levinasiana, pois o Rosto do educando, no processo educativo "[...] simultaneamente nos pede e nos ordena, isto é, interpelanos, pede-nos na condição ética de nos ordenar” (COUTINHO, 2008, p. 47).

No momento em que se assume o compromisso de atuar como educador, esse recebe a incumbência de possibilitar ao educando um ambiente favorável à elaboração de conhecimentos. Ao limitar a própria responsabilidade, o professor afasta-se da filosofia do Rosto, pois “a Transcendência da Totalidade ontológica do Mesmo ao Outro se dá pela abertura à palavra do Outro, que emerge em meu mundo como um Rosto" (COUTINHO, 2008, p. 49).

Concordamos com a ideia de Costa, ao ponderar que "a relação educador-educando, queiramos ou não, é uma relação de compromisso, é geradora de responsabilidade. Temos de nos sentir responsáveis pelo outro. Não podemos ter uma atitude de indiferença em relação ao educando" (2001, p. 90).

A análise dos discursos em busca do lugar do educando (Outro) à luz da filosofia levinasiana leva-nos a profundas reflexões, que podem parecer utópicas no contexto social contemporâneo. Entretanto, essa é uma discussão necessária para a busca de um resgate da ética nas relações entre educador e educando, ao construírem novos conhecimentos. As fortes afirmativas emergentes na construção teórica se fundamentam na radicalidade proposta pela teoria de Lévinas, na qual o processo de ensinar e aprender "não reduz o Outro ao Mesmo, mas questiona esta estrutura balizada no ensino proveniente da mesmidade" (ALVES; GHIGGI, 2012, p. 585).

A educação não se desenvolve por meio do egoísmo do Eu, mas em um movimento de sair de si em direção ao Outro. Surge, assim, a pedagogia do Outro, na qual se pretende uma atuação educacional radicalmente responsável pelo processo de aprendizagem do educando em sua total alteridade. Acreditamos que esse seria o ideal nas relações entre educador (Eu) e educando (Outro) na esteira da ética da alteridade radical.

\section{Reflexões finais}

A educação, na perspectiva levinasiana, exige o respeito absoluto pelo totalmente Outro (educando). Qual seria o papel do educador-bacharel nesse contexto? Essa perspectiva da educação requer um educador preocupado com a constituição do educando e responsável pelo desenvolvimento desse último como ente para a vida, não somente para a atuação profissional em uma área específica.

A função do educador $(\mathrm{Eu})$ sob o prisma da ética da alteridade radical é contribuir para o caminho do educando (Outro) na elaboração do próprio conhecimento, situando-o em primeiro lugar no processo de ensino-aprendizagem, e formar para cidadania, responsabilidade e ética, preparando-o para além do domínio de conteúdo de uma determinada área. O educador deve ser exemplo de atuação ética, a qual não pode simplesmente ser ensinada; precisa ser vivida para que seja possível assumir responsabilidade pelo educando em seu caminho rumo ao conhecimento.

Discutir acerca do lugar do educando na atuação do educador-bacharel universitário, na perspectiva da ética da alteridade radical, possibilitou refletir sobre a responsabilidade do educador 
(Eu) pela aprendizagem do educando (Outro). O termo "radical", a princípio, leva-nos à ideia de uma responsabilidade radical pela aprendizagem. Antes, porém, dessa consideração, é preciso compreender o significado de ensinar e aprender como processos diferentes e inter-relacionados. Ensinar refere-se a uma função do educador, ao passo que aprender se relaciona ao papel do educando. A aprendizagem depende do educando; entretanto, é dever do educador utilizar estratégias de ensino que lhe proporcionem o melhor aprendizado possível. Além disso, é praticável perceber que o educando não está se desenvolvendo como previsto nos objetivos de uma disciplina.

Entendemos que a responsabilidade pela aprendizagem, sob a visão da ética da alteridade radical, significa ter um compromisso absoluto e intransferível de possibilitar todas as condições necessárias para que a aprendizagem aconteça, acolhendo as diferenças do educando. É preciso identificar as suas necessidades no sentido de adaptar ou modificar os métodos de ensino sempre que for percebido o chamado do educando como Outro que exige uma resposta.

A investigação denota que os educadores-bacharéis investigados assumem a responsabilidade pelo educando, porém que alguns consideraram sentir-se parcialmente responsáveis pela aprendizagem, indicando uma lacuna em relação à responsabilidade levinasiana que considera o Eu totalmente responsável pelo Outro.

A responsabilidade pelo educando como Outro requer ir além da aprendizagem, contribuindo para a formação de profissionais éticos e também responsáveis. Para tanto, sob o prisma da filosofia levinasiana, o educando deve estar no centro desse processo: eis o lugar do educando como Outro. O educador ( $\mathrm{Eu}$ ) sai de si mesmo ao encontro do educando (Outro) e abandona o lugar de poder e domínio do conhecimento, o qual é ocupado pelo educando (Outro). O educando (Outro) vem antes do educador $(\mathrm{Eu})$, em primeiro lugar.

Inferimos, portanto, que o bacharel se constitui como educador de modo intuitivo, não intencionalmente. O educando (Outro) fundamenta a sua razão de ser por invocá-lo a oferecer respostas concedidas espontaneamente. Essas manifestações, não intencionais, estabeleceram a oportunidade de situar o bacharel como um educador atuante na docência universitária para além do ato de ensinar, contribuindo para a formação de cidadãos responsáveis e éticos, acolhendo o educando como Rosto no sentido levinasiano, colocando-o em primeiro lugar no processo de ensino-aprendizagem.

Por outro lado, essa ação espontânea revela a necessidade de incluir nas discussões acerca da constituição do bacharel como educador universitário, além da necessidade de formação pedagógica, espaços que possibilitem reflexões acerca da subjetividade da relação entre educador-bacharel (Eu) e Educando (Outro), de modo que sejam percebidas e respeitadas as diferenças do educando, permanentemente Outro.

\section{Notas}

1. Os termos "Outro", "Eu" e "Mesmo", como na maioria dos textos levinasianos, são apresentados com iniciais maiúsculas, a fim de se destacar os indivíduos envolvidos na relação ética.

2. Disponível em: https://pt.surveymonkey.com

3. “[...] um encontro daquele que conhece com quem não conhece, do professor com o aluno, em um exercício de transmissão de saberes, mas o encontro daquele que se conhece responsável pelo outro, obrigado a lhe dar uma resposta em situação de alteridade radical” (RUIZ, 2004, p. 8, tradução livre). 


\section{Referências}

ALVES, M. A. GHIGGI, G. Pedagogia da alteridade: O ensino como condição ético-crítica do saber em Lévinas. Educ. Soc., Campinas, v. 33, n. 119, p. 577-591, abr.-jun. 2012. https://doi.org/10.1590/ S0101-73302012000200013

ALVES, R. Conversas com quem gosta de ensinar. São Paulo: Cortez, 1980.

ALVES, R. A alegria de ensinar. 3. ed. São Paulo: Papirus, 1994.

ALVES, R. O desejo de ensinar e a arte de aprender. Campinas: Fundação Educar D’Paschal, 2004.

ARDOINO, J. Pensar a multirreferencialidade. In: MACEDO, S.; BARBOSA, J. G.; BORBA, S. (orgs.). Jacques Ardonio \& a Educação. Belo Horizonte: Autêntica, 2012, p. 87-99.

BARDIN, L. Análise de conteúdo. Lisboa: Ed. 70, 2009. 231p.

BERRY, K. S. Estruturas da bricolagem e da complexidade. In: KINCHELOE, J. L.; BERRY, K. S. Pesquisa em educação: Conceituando a bricolagem. Porto Alegre: Artmed, 2007, p. 123-148.

CAVALCANTI, B. C. A entrevista compreensiva ou o elogio da pequena teoria. In: KAUFMANN, J-C. A entrevista compreensiva: Um guia para pesquisa de campo. Trad. Thiago de Abreu e Lima Florêncio. Petrópolis: Vozes, 2013, p. 7-19.

COSTA, A. C. G. O professor como educador: Um resgate necessário e urgente. Salvador: Fundação Luís Eduardo Magalhães, 2001. 180p.

COUTINHO, A. M. F. Educar depois de Lévinas: Para uma pedagogia do rosto. 123f. 2008. Dissertação (Mestrado em Educação) - Universidade Federal de Pernambuco, Recife, 2008. Disponível em: <http:// repositorio.ufpe.br:8080/xmlui/handle/123456789/4328>. Acesso em: 27 mai. 2016.

DENZIN, N. K.; LINCOLN, Y. S. A disciplina e a prática da pesquisa qualitativa. In: DENZIN, N. K. O planejamento da pesquisa qualitativa: Teorias e abordagens. Porto Alegre: Artmed, 2006, p. 15-41.

FREIRE, P. Pedagogia do oprimido. 17. ed. Rio de Janeiro: Paz e terra, 1987.

FREIRE, P. GAMBOA, S. S. Pesquisa em educação: Métodos e epistemologias. 2. ed. Chapecó: Argos, 2012.

GIL, A. C. Métodos e técnicas de pesquisa social. São Paulo: Atlas, 2006.

GUEDES, E. C. Alteridade e diálogo: Uma meta-arqueologia da educação a partir de Emmanuel Lévinas e Paulo Freire. 2007. 181f. Tese (Doutorado em Educação) - Programa de Pós-Graduação em Educação, Universidade Federal da Paraíba, João Pessoa, 2007. Disponível em: <http://tede.biblioteca.ufpb.br/handle/ tede/4795\#preview-link0>. Acesso em: 14 abr. 2017.

HUTCHENS, B. C. Compreender Lévinas. 2 ed. Rio de Janeiro: Vozes, 2009. 239p.

KAUFMANN, J. A entrevista compreensiva: Uma proposta para pesquisa de campo. Trad. Thiago de Cavalcante e Lima Florêncio. Petrópolis: Vozes, 2013.

KINCHELOE, J. L. Introdução: O poder da bricolagem: ampliando os métodos de pesquisa. In: 
KINCHELOE, J. L.; BERRY, K. S. Pesquisa em educação: Conceituando a bricolagem. Porto Alegre: Artmed, 2007a. p. 15-37.

KINCHELOE, J. L. Redefinindo rigor e complexidade em pesquisa. In: KINCHELOE, J.L.; BERRY, K. S. Pesquisa em Educação: conceituando a bricolagem. Porto Alegre: Artmed, 2007b. p. 39-65

KINCHELOE, J. L. Redefinindo e interpretando o objeto de estudo. In: KINCHELOE, J. L.; BERRY, K. S. Pesquisa em educação: Conceituando a bricolagem. Porto Alegre: Artmed, 2007c. p. 102-121.

KINCHELOE, J. L.; BERRY, K. S. Pesquisa em educação: Conceituando a bricolagem. Porto Alegre: Artmed, 2007.

LÉVINAS, E. Totalidade e infinito. Lisboa: Ed. 70, 1980. 291p.

LÉVINAS, E. Ética e Infinito. Lisboa: Ed. 70, 1982. 117p. LÉVINAS, E.. Ética e Infinito: Diálogos com Philippe Nemo. Lisboa: Ed. 70, 1988. 119p.

LÉVINAS, E. Totalidade e infinito: Ensaio sobre a exterioridade. Trad. José Pinto Ribeiro. Lisboa: Ed. 70, 2000. 312p.

LÉVINAS, E. De Deus que vem a ideia. Petrópolis: Vozes, 2002. 240p.

LÉVINAS, E. Entre nós: Ensaios sobre a alteridade. Trad. Pergentino Stefano Pivatto (coord.); Evaldo Antônio Kuiava; José Nedel; Luiz Pedro Wagner; Marcelo Luiz Pelizolli. 2. ed. Petrópolis: Vozes, 2005. 302p.

MARTINS, R. J.; LEPARGNEUR, H. Introdução a Lévinas: Pensar a ética no século XXI. São Paulo: Paulus, 2014. 72p.

MIRANDA, J. V. A. Ética da alteridade e educação. 2008, 188f. Tese (Doutorado em Educação) Universidade Federal do Rio Grande do Sul, Porto Alegre, 2008. Disponível em: <https://www.lume.ufrgs. br/bitstream/handle/10183/14654/000658924.pdf? sequence=1>. Acesso em: 27 mai. 2016.

MOURA, A. B. F.; LIMA, M. G. S. B. A reinvenção da roda. Roda de conversa: Um instrumento metodológico possível. Revista Temas em Educação, João Pessoa, v. 23, n. 1, 2014, p. 98-106. Disponível em: https:// periodicosonline.uems.br/index.php/interfaces/article/view/448. Acesso em: 3 jan. 2017.

NEIRA, M. G; LIPPI, B. G. Tecendo a colcha de retalhos: A bricolagem como alternativa para a pesquisa educacional. Educação e Realidade, v. 37, n. 2, pp. 607-625, 2012. https://doi.org/10.1590/ S2175-62362012000200015

OLIVEIRA, M. M. Como fazer pesquisa qualitativa. 3. ed. Petrópolis: Vozes, 2010. 192p.

PALMER, R. Hermenêutica. Lisboa: Ed. 70, 2006. 288p.

RUIZ, P. O. L. A educación moral como pedagogía de la alteridad. Revista Española de Pedagogia, año LXII, n. 227, mar.-abr 2004, p. 5-30. Disponível em: $<$ https://dialnet.unirioja.es/servlet/articulo? codigo=866846 $>$. Acesso em: 24 ago. 2016.

VOSGERAU, D. S. R.; ORLANDO, E. A.; MEYER, P. Produtivismo acadêmico e suas repercussões no desenvolvimento profissional de professores universitários. Educ. Soc., Campinas, v. 38, n. 138, p.231247, jan.-mar., 2017. https://doi.org/10.1590/es0101-73302016163514 


\section{Sobre a Autora}

Conceição de Maria Pinheiro Barros é doutora em Educação pela Universidade Estadual do Ceará (UECE). Mestra em Políticas Públicas e Gestão da Educação Superior e Bacharela em Secretariado Executivo pela Universidade Federal do Ceará (UFC). Professora da UFC.

Recebido: 18 Jun 2019

Aceito: 12 Fev 2020 